\title{
SENI PERHIASAN DALAM KEBUDAYAAN MATARAM KUNO SEBAGAI SUMBER PEMBELAJARAN SEJARAH (STUDI IKONOGRAFI RELIEF CANDI BOROBUDUR)
}

\author{
Oleh: Ari Irawan*, Muhamad Idris** \\ *Mahasiswa Program Studi Pendidikan Sejarah FKIP Universitas PGRI Palembang \\ ${ }^{* *}$ Dosen Program Studi Pendidikan Sejarah FKIP Universitas PGRI Palembang
}

\begin{abstract}
ABSTRAK
Candi Borobudur menyimpan nilai sejarah yang tinggi relief perhiasan pada dindingnya. Belum semua data dan informasi sejarah tersebut dapat dimanfaatkan pada pembelajaran sejarah di sekolah. Permasalahan dalam penelitian ini adalah nilai sejarah apakah dari pakaian pada kebudayaan Mataram kuno yang dapat dimanfaatkan sebagai sumber pembelajaran sejarah?.Tujuan penelitian mengetahui relief seni perhiasan dalam kebudayaan Mataram kuno studi ikonografi relief candi Borobudur. Metode dalam penelitian ini adalah deskriptif kualitatif yaitu menggunakan cara mengumpulkan sumber-sumber secara sistematis dan menggunakan sumber data secara mendalam. Minimal ada tiga hal yang digambarkan dalam penelitian kualitatif, yaitu karakteristik pelaku, kegiatan, atau kejadian-kejadian yang terjadi selama penelitian, dan keadaan lingkungan atau karakteristik tempat penelitian berlangsung. Teknik pengumpulan data melalui observasi, dokumentasi dan wawancara. Hasil penelitian: masyarakat Mataram kuno menggunakan perhiasan sesuai dengan status sosial mereka di dalam masyarakat, ditemukan 7 jenis perhiasan yang diabadikan pada relief candi Borobudur.
\end{abstract}

Kata Kunci: Seni Perhiasan, Kebudayaan Mataram Kuno, Sumber Pembelajaran Sejarah.

\section{A. PENDAHULUAN}

Candi Borobudur terletak di Pulau Jawa, dengan pusat yang menjulang ke angkasa dikelilingi bukit Menoreh yang membujur dari arah Timur ke Barat dan gunug-gunung berapi. Merapi dan Merbabu disebelah Timur, Sumbing dan Sindoro di sebelah Barat, dengan pemandangan yang hijau indah membentang sejauh mata memandang. Kesemuanya itu menimbulkan suasana tenang, aman, dan tenteram. Borobudur termasuk ke dalam wilayah kabupaten Magelang eks Karesidenan Kedu, Jawa Tengah. Dari Yogyakarta, jaraknya $41 \mathrm{~km}$ kearah Utara melalui jalan raya menuju Magelang. Tempat candi itu dapat ditempuh dengan mudah dan sarana perhubungannya sudah baik. Arti Borobudur sampai sekarang belum diketahui secara jelas. Namun, nama Borobudur berasal dari bangunan kata-kata Bara dan Budur. Bara berasal dari kata Sansekerta Vihara, yang berarti kompleks candi dan bihara atau asrama. Sedangkan kata Budur mengingatkan kita pada bahasa Bali: Beduhur, yang berarti di atas. Nama Borobudur kira-kira berarti asrama atau bihara (kelompok candi) yang terletak di atas bukit. Dihalaman sebelah Barat Laut Borobudur sewaktu diadakan penggalian ditemukan sisa-sisa bekas sebuah bangunan, yang mungkin sekali bangunan bihara. Borobudur jelas merupakan bangunan suci agama Budha. Di India, bangunan yang berhubungan dengan nama Budha disebut stupa. Stupa ialah bangunan berbentuk kubah, berdiri di atas sebuah lapik dan diberi payung di atasnya (Soetarno, 2003: 73-74).

Penamaan candi Borobudur masih menjadi pertanyaan. Kata Borobudur yang dipakai untuk penyebutan bangunan. Berdasarkan penjelasan masyarakat yang bertempat tinggal disekitar candi Borobudur menceritakan bahwa pada zaman dahulu disekitar candi Borobudur tumbuh dengan subur pohon budur, yang diartikan sebagai pohon bodhi atau pohon kehidupan. 
Bagi masyarakat desa, khususnya disekitar candi Borobudur, istilah yang lazim dipakai adalah budur untuk penamaan bangunan suci tersebut. J.L. Moens dalam artikelnya yang berjudul Borobudur Mendut en Pawon en hun onderlinge samen I-II mengartikan istilah budur dengan kota Budha. Lain lagi pendapat Poerbatjaraka, seorang putra bangsa Indonesia yang ahli dalam bahasa Jawa Kuno. la mengatakan bahwa Borobudur berasal dari kata biara (tempat suci atau kuil) dan bidur yang berarti tempat tinggi. Maka arti kedua kata tersebut menjadi kuil yang berada ditempat yang tinggi (Prasetyo, 1993:14-15).

Dalam khazanah sejarah budaya bangsa Indonesia, candi Borobudur merupakan salah satu bukti penguasaan ilmu pengetahuan dan teknologi yang sangat canggih. Bangunan besar, kokoh dan megah dari abad ke-8 Masehi dengan gaya arsitektur yang sangat rumit dan menakjubkan itu menjadi primadona pada zamannya, sekaligus sebagai tanda kejayaan dan kemakmuran masyarakat Jawa kuno pada masa itu. Dari data prasasti, candi-candi dan tinggalan arkeologi lainnya diperoleh berita bahwa pada pertengahan abad ke-7 Masehi sampai pertengahan abad ke-10 Masehi, wilayah Jawa Tengah dibawah kekuasaan dua dinasti, yaitu dinasti Syailendra dan dinasti Sanjaya. Kedua dinasti tersebut membangun berpuluh-puluh candi di wilayah Jawa Tengah, antara lain. candi Dieng, candi Gedong Songo, candi Borobudur, candi Prambanan, candi Sewu, candi Plaosan, candi Kalasan, dan kraton Ratubaka. Selain itu, mereka juga mengeluarkan beberapa prasasti sebagai tanda peresmian Sima (daerah perdikan), bangunan suci dan silsilah raja (Prasetyo, 1993:19).

Sebagaimana lazimnya pada bangunan-bangunan candi lainnya, relief maupun hiasan-hiasan yang dipahatkan pada masing-masing tingkat candi
Borobudur melambangkan kosmos, relief dan hiasan mewujudkan apa yang ada di dalam semesta ini. Relief dan hiasan yang ada pada candi Borobudur menggambarkan kehidupan masyarakat sehari-hari, sehingga unsur-unsur khas Indonesia sangat menonjol seperti adanya relief perahu bercadik, rumah panggung, bertani, peperangan, pertunjukan kesenian, mencari ikan, fauna dan flora (Prasetyo, 1993:28).

\section{B. METODE PENELITIAN}

Metode penelitian deskriptif kualitatif menggunakan cara mengumpulkan sumber-sumber secara sistematis dan menggunakan sumber data secara mendalam. Penelitian deskriptif kualitatif diuraikan dengan kata-kata menurut responden, apa adanya sesuai dengan pertanyaan penelitiannya, kemudian dianalisis dengan kata-kata apa yang melatarbelakangi responden berperilaku (berpikir, berperasaan, dan bertindak) seperti itu tidak seperti lainnya, direduksi, ditriangulasi, disimpulkan (diberi makna oleh peneliti), dan diverifikasi (dikonsultasikan kembali kepada responden dan teman sejawat). Minimal ada tiga hal yang digambarkan dalam penelitian kualitatif, yaitu karakteristik pelaku, kegiatan, atau kejadian-kejadian yang terjadi selama penelitian, dan keadaan lingkungan atau karakteristik tempat penelitian berlangsung (Akbar, 2014:130).

Metode penelitian merupakan cara yang digunakan oleh peneliti dalam mengumpulkan data penelitiannya. Seperti sudah dijelaskan, variasi dimaksud yaitu: angket, wawancara, pengamatan atau observasi, tes, dokumentasi (Arikunto, 2013:203). 


\section{HASIL DAN PEMBAHASAN Gambaran Umum Latar Penelitian Candi Borobudur}

Menurut Soekmono dalam Noerhadi (2012:1) diantara candi-candi di Jawa yang menarik perhatian ialah candi Borobudur, tidak hanya tampak dari susunan bangunannya akan tetapi juga disebabkan banyaknya pahatan-pahatan reliefnya yang mengisi seluruh permukaan dindingnya dan pagar langkannya. Pulau Jawa kaya akan peninnggalan-peninggalan purbakala, diantaranya ialah bangunan-bangunan purbakala yang biasanya disebut candi. Candi-candi ini tersebar di Jawa Tengah dan Jawa Timur, dinding-dinding candi ini dihiasi dengan relief, hiasan ini bukan penghias atau pengisi bidang, tetapi melukiskan suatu cerita. Banyak dari dari candi-candi di Jawa memiliki relief, misalnya candi Loro Jonggrang menggambarkan relief cerita Ramayana yang terdapat pada langkan candi Ciwa dan diteruskan pada langkan candi Brahma, juga terdapat cerita Krsnayana pada langkan wisnu. Pada candi Jago kita temukan juga relief-relief cerita krsnayana, Parthayajna dan Kunjarakarna. Pada relief candi induk di Panataran dijumpai relief Ramayana dan Krsnayana, dan masih banyak candi-candi di Jawa yang mempunyai relief cerita (Noerhadi, 2012:1).

Sejak dibangun pada abad ke-8 Maasehi (antara 750 dan 850 Masehi), sejarah candi Borobudur timbul-tenggelam. Kemegahan candi Budha di Jawa Tengah ini tidak berlangsung lama. Seiring dengan merosotnya agama Budha Mahayana di tanah Jawa, candi Borobudur dilupakan begitu saja. Setelah dinasti Syailendra runtuh, candi Borobudur ikut tenggelam. Selama berabad-abad, candi raksasa yang dibangun oleh raja dari dinasti Syailendra, raja Samaratungga sekitar tahun 824 Masehi dan baru diselesaikan pada masa putrinya, ratu Pramodhawardhani, yang konon memakan waktu sekitar 50 tahun tertutup kegelapan. Seiring dengan perpindahan pusat kerajaan Jawa ke wilayah Jawa bagian timur, praktis candi Borobudur menjadi media tumbuh suburnya berbagai jenis ilalang, rumput, dan semak belukar. Pohon-pohon kecil tumbuh subur, menjadikan candi Borobudur seperti gundukan batu yang tertutup belukar (Raffles, 2015: VIII-IX).

Sebelum masuknya pengaruh HinduBudha, masyarakat Indonesia telah mengenal budaya punden berundak yang sering dihubungkan dengan kepercayaan animisme dan dinamisme atau pemujaan terhadap leluhur. Candi Borobudur dan bangunan diakhir masa Majapahit (candicandi di lereng gunung Penanggungan, Arjuna, dan Lawu) dibangun dengan mengambil bentuk punden berundak-undak meskipun kedua kerajaan tersebut bercorak Hindu dan Budha. Gejala ini menunjukan ada akulturasi didalam perubahan budaya, pengaruh Hindu-Budha jelas telah menyentuh lapisan elite istana dibandingkan lapisaan masyarakat bawahannya sehingga memungkinkan kepercayaan kuno masih dianut sebagian besar penduduknya. Hasil kebudayaan Hindu-Budha yang paling menonjol dan menjadi ciri khas budaya periode tersebut adalah bangunan candi yang megah dan indah sebagai hasil karya arsitektural yang monumental. Candi merupakan istilah yang digunakan untuk menyebut semua bangunan peninggalan di Indonesia yang dipengaruhi oleh arsitektur Hindu-Budha. Istilah candi dikaitkan dengan istilah candika yaitu salah satu nama dewi Durga atau dewi kematian, sehingga candi sering dikaitkan kematian, makam atau sebagai tempat untuk memuliakan raja yang meninggal. Terkait dengan fungsinya sebagai pemakaman, sebenarnya yang disimpan hanyalah pripih, yaitu sebuah wadah yang berisi antara lain zat-zat ragawi dari si mati seperti potongan rambut, kuku, dan lainnya. Pengertian candi sebagai tempat pemakaman hanya berlaku bagi penganut agama Hindu. 
Dalam agama Budha, candi merupakan bangunan peribadatan, di Jawa candi-candi dikaitkan sebagai tempat suci untuk mengagungkan para penguasa melalui kaitan mereka dengan dewata (Darini, 2013: 56-60).

Bangunan itu merupakan bangunan batu berbentuk segi empat, dengan dinding tujuh tingkat, yang tiap-tiap jaraknya semakin berkurang saat didaki hingga akhir bangunan yang bentuknya seperti kubah. Keseluruhan bangunan berbentuk kerucut, dengan bagian atas terpotong hingga bagian dinding, dan untuk melengkapinya diberi figur pada seluruh struktur bangunan. Dibagian tengah, bersandar pada bagian puncak bukit, merupakan suatu kubah yang belum diterangkan, dengan diameter kurang lebih 50 kaki, dan itu tinggal reruntuhan dimana bagian atas telah runtuh, hanya tinggal 20 kaki tingginya. Pada bagian atasnya terdapat tiga menara dengan lingkaran berjumlah 22, tiap-tiap bagian terdapat gambaran dan semua dihubungkan dengan sebuah batu yang menutupi bukit yang menampakkan bentuk atap, turun dari bagian atas kita akan melewati tiap sisi bangunan melalui tangga melewati lima buah pintu gerbang menawan, yang mempunyai lima buah teras, mengelilinngi bukit pada tiap sisinya. Dinding yang mendukung teras ini ditutupi dengan bagian dalam teras dan membentuk sebuah sandaran di sisi lain. Pada bagian eksterior sandaran ini, pada jarak yang sama sebuah relung masingmasing berisi sebuah figur telanjang duduk bersila sangat menarik. Keseluruhan jumlahnya tidak kurang dari 400. Bagian atas tiang relung merupakan sebuah menara kecil, ada yang terletak dibagian atas lain dari relung, ada yang terdapat di sisi relung. Desainnya teratur, arsitektural dan paham ornamennya sangat banyak. Bas relief dihadirkan dengan sangat beragam, mengambil kisah mitologi, yang dikerjakan dengan penuh perasaan dan kemampuan. Keseluruhan area dari bangunan yang indah ini luasnya sekitar 620 persegi. Bagian eksterior berupa tanah datar berbentuk segi empat sempurna. Jika dilihat pada jarak tertentu, bentuk sebenarnya bukan seperti yang digambarkan, tetapi mempunyai pusat disetiap sisi, untuk luasnya diperkirakan beberapa kaki, dan juga sebagai penutup sebagian besar tanah dengan bukit berbentuk kerucut bentuk yang sama juga terdapat di tiap-tiap teras, secara keseluruhan candi Borobudur merupakan bangunan yang kokoh, dan tingginya sekitar 100 kaki, puncak menara 20 kaki, namun telah runtuh, hampir semua bagian interior merupakan bukit itu sendiri (Raffles, 2015: 374-375).

Para ahli sejarah kuno dan arkeologi Indonesia telah sepakat bahwa para pembangun candi tersebut adalah Syailendra wangsa dan kaum kerabatnya. Mereka rela bekerja keras dibantu oleh rakyatnya membangun monumen keagamaan megah demi untuk kepentingan peribadatan dan tanda pengabdian yang mendalam kepada sang Budha. Maka menjelmalah satu bangunan yang unik tiada duanya di dunia ini, yaitu suatu bentuk perpaduan antara teras-teras bertingkat dan bermacam bentuk stupa dalam berbagai ukuran. Di puncak terasteras tersebut terdapat mahkota stupa besar simbol dari keagungan agama Budha dan juga lambang pertemuan antara dunia manusia dan dunia dewa-dewa. Candi Mendut dan candi Borobudur mempunyai hubungan yang begitu dekat. Beberapa butir penghubung ketiga candi itu adalah; (1) ketiga candi tersebut terletak di suatu garis lurus; (2) ketiganya bernafaskan agama Budha Mahayana; (3) dihias dengan bentuk komponen arsitektur dan ornamen yang sama, misalnya hirayagarbha, sulur daun, kalpataru, kalasa dan lain sebagainya; (4) tangga naik utama candi Borobudur berada disisi timur, di arah tersebut terdapat candi Pawon dan Mendut. Jadi seakan-akan menghadap ke arah 
kedatangan para peziarah masa silam dari arah candi Mendut dan candi Pawon (Munandar, 2009:3).

Ajaran Budha Mahayana, terdapat dua konsep penting, yaitu Lakottara dan Laukika. Seseorang yang akan menjadi Budha harus melalui dua jalan di dunia dulu, dua jalan Laukika, yaitu Sambharamarga dan Prayogamarga. Adapun Lokottara merupakan dunia di atas dunia manusia , dunia dewa-dewa yang terdiri dari 10 tingkat ke-Budhaan atau Dasabhoddhissatvabhumi. Lokottara adalah dunia tujuan akhir dari para pemeluk Budha sebelum mencapai tingkat ke-budhaan yang tertinggi. Pada bangunan candi, Sambharamarga disimbolkan pada candi Mendut, Prayogamarga pada candi Pawon dan Lokottara disimbolkan pada candi Borobudur. Candi Borobudur terletak di permukaan bukit sebagai lambang "dunia atas" dan terdiri dari 10 tingkat lambang dari Dasabhoddhisatvabhumi. Terdapat satu lagi candi yiatu candi Ngawen yang ternyata dari perspektif arkeologis mempunyai beberapa persamaan dengan candi Mendut, candi Pawon dan candi Borobudur. Persamaan itu terlihat pada komponen arsitekturnya dan juga pada ornamen yang diterakan pada candi Ngawen. Candi Ngawen secara hipotesis mempunyai hubungan dengan ketiga candi Budha Mahayana Lainnya (Munandar, 2009:3).

Relief-relief pada candi Borobudur ada yang merupakan relief cerita dan relief hiasan raja. Relief-relief yang menggambarkan cerita dibagi menurut adegannya menjadi pigura-pigura yang semuanya berjumlah 1460 pigura, reliefrelief yang berupa hiasan dipahat ke dalam pigura-pigura yang masing-masing terpisah dan seluruhnya berjumlah 1212 pigura. Deretan pertama relief cerita itu terdapat pada dinding kaki candi yang tertutup. Relief-relief ini telah diabadikan dalam fotofoto, sehingga semua pigura-pigura yang berjumlah 160 dapat diketahui sebagai penggambaran berlakunnya hukum karma menurut kitab suci Mahakarmawibangga. Dinding lorong pertama dihiasi dengan dua baris relief yang tersusun masing-masing terdiri dari 120 pigura. Relief barisan atas menceritakan riwayat hidup sang Budha menurut kitab suci Lalitavistara, sedangkan deretan bawah berupa cerita-cerita Jataka yang menggambarkan kehidupan sang Budha dalam penjelmaan-penjelmaannya sebelum menjadi sang Budha, dan ceritacerita Awadana. Pada langkan lorong pertama diteruskan dengan relief cerita Jataka atau Awadana, sedangkan reliefrelief pada dindingnya menggambarkan Sudhanakumara yang diambil dari kitab suci Gandawyuha yang dibagi menjadi 128 pigura. Pada lorong ketiga dan keempat terdapat cerita yang merupakan lanjutan dari penggambaran Sudhanakumara dan relief cerita Bhadracari yang dipahatkan pada dinding candi dan pagar langkannya (Noerhadi, 2012: 2).

\section{Letak}

keberadaan candi Borobudur sebagai monumen peradaban Budha di Indonesia, Khususnya di Jawa Tengah, tidak dapat dipisahkan dari keunikan aspek-aspek keberadaan keterampilan seni bangunan atau patung, teknik, dan organisasi membangun, serta keberadaanya bagi masyarakat saat itu. Borobudur sebagai monumen historis bukan karena semata-mata monumentalis bentuk dan bangunannya, tetapi juga kaitannya antara bangunan Borobudur dengan peradaban yang mendukungnya (Wiryomartono, 1995: 67).

Dari tahun 1811 sampai 1815 negara Indonesia menjadi jajahan Inggris. Kepala pemerintah jajahan adalah Sir Thomas Stamfod Raffles, yang berkedudukan di Jakarta tetapi sering berkeliling pulau Jawa karena minatnya yang luar biasa terhadap sejarah. Dalam tahun 1814 ia sedang berkunjung ke Semarang, ketika diberitahukan kepadanya akan adanya sebuah candi di Desa Bumisegoro dekat 
Magelang, yang belum ia kenal dan oleh masyarakat disebut Borobudur (Soekmono, 1991: 12).

Pada tahun 1814 Thomas Stamford
Raffles mendengar berita adanya
penemuan benda purbakala di sekitar
Magelang, Jawa Tengah. Raffles kemudian
mengutus Cornelius untuk menyelidiki
lokasi penemuan berupa bukit yang
dipenuhi semak belukar. Raffles
memerintahkan agar "bukit ilalang" itu
dibersihkan, sehingga tampaklah sebuah
candi raksasa yang dipenuhi patung Budha
Mahayana. Sejak itu, candi Borobudur
banyak dikunjungi orang (Raffles, 2015:
IX).
Posisi

Di Desa Borobudur Provinsi Jawa Tengah, di dekat pertemuan sungai Elo dan sungai Progo, di atas sebuah bukit berdiri candi Borobudur. Bangunan ini oleh beberapa orang diduga dibangun abad keenam, sementara oleh beberapa yang lain menduga dibangun abad kesepuluh tahun Jawa. Dekat dengan bangunan menakjubkan ini ditemukan sebuah sosok batu yang terputus anggota tubuhnya, yaitu Brahma. Dan tidak begitu jauh, beberapa yard dari pertemuan sungai Elo dan sungai Progo, terdapat sisa-sisa dari beberapa candi yang indah dan bentuknya menarik dalam bentuk dan desain yang hampir sama dengan tetangganya, Prambanan. Pada relung dan dinding terdapat relief beberapa figur dengan perlengkapannya, sesuai dengan kebiasaan para Brahma. Sebagian besar dari mereka memiliki beberapa perlengkapan yang lengkap, dan ini merupakan sesuatu yang luar biasa mengingat di Borobudur terdapat gambaran figur-figur ini (Raffles, 2015: 374-375).

\section{Hasil Penelitian \\ Klasifikasi Sosial Masyarakat Mataram Kuno}

Dalam masyarakat Mataram kuno banyak dijumpai pejabat-pejabat ditingkat watak (daerah) yang jumlahnya ratusan.
Dari nama-nama tersebut tentunya dapat diprediksi bagaimana keadaan sosial masyarakat pada saat itu. Jabatan-jabatan tersebut antara lain: rama magman atau rama mangagem kon (pejabat desa yang masih memegang perintah), tuha wanua merupakan orang yang tertua di suatu desa, dan karena itu dianggap sebagai kepala desa. Hulu-air atau hulair, merupakan pejabat yang mengurusi masalah pengairan di desa (di Jawa zaman sekarang disebut sebagai ulu-ulu). Tuha alas, mengurusi hutan yang ada di dalam wilayah desanya. Wariga, di Bali kata Wariga ini adalah semacam primbon untuk menentukan hari-hari baik, istilah ini digunakan untuk pejabat yang bertugas menghitung hari-hari baik untuk suatu pekerjaan di desa. Tuha wereh, semacam pemimpin para pemuda pemudi di desa. Parujar, adalah semacam juru bicara, winekas yang berarti "pesan", sehingga tugasnya berhubungan dengan menyampaikan berita kepada penduduk atau desa tetangga. Hulu waras berhubungan dengan persediaan beras atau padi di desa, dengan demikian pejabat yang mengurusi pasar, matarman pejabat yang mengurusi pertamanan, tuha baru ialah pejabat yang mengurusi perburuan binatang di hutan. Tuha gusali ialah pejabat yang mengurusi jembatan atau penyeberangan. Hulu turus atau mawatas ialah pejabat yang mengurusi perbatasan antara desa yang satu dengan desa lain, atau mengurusi batas-batas tanah penduduk (Suwardono, 2013: 111-112). Jumlah pejabat di suatu desa tidak sama dengan desa yang lainnya, dilihat dari kebutuhan pekerjaan yang ada. Dari banyaknya jumlah pejabat-pejabat yang mengurusi semua aspek pekerjaan di desa, dapatlah dibayangkan kondisi sosial masyarakat Mataram kuno saat itu, interaksi sosial masyarakatnya sudah cukup kompleks dan tertata. Dari segi ekonomi dapat diketahui bahwa masyarakat Mataram kuno pada waktu itu 
sudah melakukan perdagangan individu dan pasar. Dagangan mereka ada yang dipikul dan ada pula yang diangkut dengan pedati, ada pula yang dibawa dengan perahu. Dengan disebutkannya pedati (magulungan atau magilingan) sebagai sarana transportasi perdagangan, dapat dibayangkan adanya perdagangan antar desa dan antar wilayah di luar desa. Adanya beberapa istilah untuk menyebut pedagang, yaitu abakul, adagang, dan bangyaga. Istilah masamwyawahara mungkin dipakai istilah pedagang dalam pengertian umum, dalam bahasa Jawa sekarang ada istilah bakul sinambewara (Suwardono, 2013: 112).

Di dalam kesusasteraan seperti Nagarakertagama dan di dalam berbagai prasasti banyak sekali disinggung tentang pembagian golongan masyarakat ke dalam kasta-kasta (caturwarna), yaitu kasta Brahmana, kasta Ksatrya, kasta Waisya dan kasta Sudra. Mengenai pembagian kasta di India tidak sesuai dengan kenyataan yang ada di Indonesia. Pigeud membagi masyarakat Jawa kuno ke dalam empat kelas yang terdiri dari kaum penguasa, kaum agama, orang biasa dan budak. Dengan demikian masyarakat Jawa kuno terbagi menjadi tiga golongan utama, yaitu golongan penguasa, golongan agama dan golongan rakyat biasa. Casparis berpendapat bahwa adanya pembagian kasta yang dikenal di Indonesia ini peraturannya tidak sekeras yang tedapat di India. la membagi masyarakat Jawa kuno ke dalam tiga golongan: 1) Golongan pertama, yang terbesar jumlahnya adalah penduduk desa dan seluruhnya. 2) Golongan kedua adalah sang prabu dengan segenap kaum keluarganya dan mereka yang langsung tergantung kepada sang prabu, dengan mudah dapat kita sebut golongan keraton. 3) Golongan ketiga golongan agama, antara lain pedanda-pedanda di candi-candi, orangorang yang tinggal di wihara-wihara dan pegawai-pegawai rendahannya (Noerhadi, 2012: 50-51).

\section{Ragam Perhiasan Mataram Kuno Perhiasan Bangsawan}

Berita-berita Cina yang menyebutkan hubungan Cina dengan kerajaan-kerajaan di Jawa disinggung pula mengenai pakaian dan perhiasan raja. Raja dan para bangsawan memakai bahan tipis dan berbunga (selendang) untuk menutupi bagian atas tubuh mereka. Memakai ikat pinggang dari emas dan anting-anting berbentuk cincin. Di dalam berita dinasti Sung dikatakan bahwa di Jawa raja menggelung rambutnya, memakai kerincingan emas (Noerhadi, 2012: 6).

Ksatria di dalam lingkungan istana mereka terdiri dari raja dan permaisuri digambarkan dengan perhiasan-perhiasan seperti kalung, anting-anting, gelang, kelatbahu, gelang tangan, gelang kaki. Yang terpenting bahwa mereka digambarkan memakai prabhamandala dan mahkota pada kepala mereka, juga menggunakan upavita. Sedangkan ksatrya di luar ruangan mereka digambarkan dengan perhiasanperhiasan seperti kalung, anting-anting, gelang, kelat-bahu. Bedanya mereka tidak mengenakan gelang kaki dan mahkota, mereka hanya berupa susunan rambut yang tinggi (Noerhadi, 2012: 79).

Kain yang digunakan oleh kaum bangsawan dirumah adalah kain tenun yang agak baru, sedangkan untuk bepergian, biasa digunakan kain yang masih baru, kain yang digunakan dalam upacara adat dan pesta-pesta lainnya, biasanya terdiri dari bahan-bahan yang lebih mahal, terkadang kain yang dibeli diluar daerah, perhiasannya pun demikian. Perhiasan dan perlengkapan yang digunakan oleh kaum bangsawan lebih mewah (Depdikbud, 1991: 18).

\section{Perhiasan Agamawan}

Brahmana atau pendeta dalam lingkunagan keraton digambarkan memakai perhiasan seperti kalung, gelang, anting- 
anting dan memakai hiasan kepala. Mereka digambarkan dengan memakai upavita dan ciri-ciri brahmana yaitu digambarkan dengan memakai kumis dan janggut. Sedangkan brahmana atau pendeta yang berada di desa atau petapaan mereka digambarkan sedang meminta-minta, tidak memakai perhiasan kalung, anting-anting dan gelang, berkumis dan berjanggut (Noerhadi, 2012: 78).

Seorang agamawan merupakan pemimpin spiritual atau religi dari setiap agama, semua aktifitas manusia yang bersangkutan dengan religi berdasarkan atas getaran jiwa, yang biasanya disebut emosi keagamaan. Emosi keagamaan ini biasanya pernah dialami oleh setiap manusia, walaupun getaran emosi itu mungkin hanya berlangsung untuk bebrapa detik saja, untuk kemudian menghilang lagi. Emosi keagamaan itulah yang membuat seseorang terdorong untuk melakukan tindakan-tindakan bersifat religi (Koentjaraningrat, 2009: 295).

\section{Perhiasan Pedagang}

Waisya atau pedagang yang terdiri dari pedagang dan buruh menengah dan pedagang yang kaya-raya, digambarkan dengan perhiasan-perhiasan seperti kalung, anting-anting, gelang, kelat-bahu dan gelang kaki. Yang terpenting adalah bahwa mereka digambarkan memakai mahkota kecil. Sedangkan waisya atau pedagang di luar bangunan mereka digambarkan sederhana dengan perhiasan berupa anting-anting saja. Tanpa mahkota kecil pada kepala mereka (Noerhadi, 2012: 79).

Terjadilah pergeseran lalu lintas ekonomi, karena kerajaan Mataram memiliki armada dagang yang kuat, Pantai Utara pulau Jawa pun mulai ramai dikunjungi perahu pedagang dari Cina, mereka datang untuk membeli hasil bumi. Perdagangan dalam negeri juga tak ketinggalan marak, cengkeh dan biji pala didatangkan dari Maluku. Demikian juga berass dan gading, serta aneka barang niaga yang digemari pedagang dari Persia. Ibukota dan lokasi istana Mataram adalah Medang. Namun beberapa bukti telah hilang karena gempa bumi, letusan gunung berapi, banjir, atau juga peperangan. Sejarah mencatat bahwa pada tahun 1007, Mataram diperintah oleh raja Darmawangsa. Namun, tempat tinggalnya dibakar, keraton musnah dalam kobaran api. Raja Darmawangsa dan seluruh keluarganya dibantai, kecuali pangeran Erlangga. Menantu Darmawangsa berhasil meloloskan diri bersama beberapa abdinya, ia bersembunyi di hutan sekitar (Suyono, 2003: 2-3).

\section{Perhiasan Rakyat Biasa}

Laki-laki dari kalangan bawah biasa menggunakan celana kain selutut, dengan jarit atau kain yang melilit pinggang dan menjuntai melewati lutut, seperti gaun pendek. Kain ini selalu diikat dipinggang dengan sabuk saat bekerja di sawah atau bepergian, tapi biasanya dilepas saat bertemu dengan orang yang lebih kuasa. Para wanitanya juga menggunakan kain yang sama dan dililitkan hingga mata kaki. Cara mengikatnya berbeda dengan laki-laki dan tidak pernah diangkat ke atas seperti mereka. Pengikat kain dinamakan udat, sedangkan kain yang dililitkan mengelilingi tubuh menutupi dada sampai dekat dengan lengan disebut kemban, mereka memakai sejenis logam atau tanduk kerbau atau kuningan sebagai anting-anting (Raffles, 2015: 54).

Perhiasan yang berupa kain yang dikenakan oleh golongan rakyat biasa memiliki motif yang lebih sederhana dibandingkan dengan golongan bangsawan, perbedaan yang mendasar terdapat pada bahan dasarnya yaitu benang yang digunakan pada proses menenun kain bagi kaum bangsawan tidak dipintal sendiri sedangkan untuk rakyat biasa diperoleh dengan cara memintal sendiri (Depdikbud, 1991: 17). 


\section{Perhiasan Nelayan dan Pemburu}

Suku bangsa di Indonesia yang mempunyai mata pencariannya di bidang kelautan (maritim) seperti Melayu, Dayak, Bugis, dan Madura. Perkembangan pengetahuan dan teknologi perahu sudah dikenal oleh masyarakat di Indonesia sejak ribuan tahun yang lalu dan terwujudkan pada lukisan-lukisan prasejarah di gua-gua yang ditemukan para arkeolog. Selain dari pengenalan teknologi pembuatan perahu, juga dijelaskan bagaimana masyarakatmasyarakat dengan tipe sosial budaya nelayan ini dapat memenuhi kebutuhan hidupnya atau pola mata pencarian yang ada, dan bagaimana teknologinya untuk mencapai kebutuhan hidup mereka (Paeni, 2009: 38).

Kemampuan teknologi pelayaran yang berkembang cukup pesat sejak zaman prasejarah membuat semakin tumbuhnya budaya bahari di Kepulauan Nusantara. Teknologi pelayaran itu tidak saja menunjang kehidupan sebagai nelayan, tetapi juga pertukaran barang atau perdagangan antar pulau. Bahkan diduga para pelaut-pedagang Austronesia telah memicu perdagangan jarak jauh antara Cina-Asia Tenggara-India sejak 2.500 tahun lalu. Keberadaan benda-benda perunggu yang disebutkan sebagai hasil budaya Dongson yang ditemukan tersebar dari Sumatera hingga Papua dibawa oleh para pelaut Austronesia sebagai barang bermartabat yang digemari oleh para pemimpin adat atau pemuka kelompokkelompok etnis di Nusantara karena dapat meningkatkan status sosial mereka. Bendabenda ini ditukar dengan hasil-hasil alam di kepulauan Nusantara antara lain kayu wangi (cendana), bulu burung, cula badak, kamper, pala dan cengkeh. Pada masa pengaruh Hindu-Budha, rupanya kehidupan sebagai nelayan tetap saja menjadi pilihan hidup yang cukup diminati. Pada relief-relief candi sering kali digambarkan cara kehidupan seperti itu. Pada salah satu relief candi Borobudur banyak digambarkan orang yang sedang menjala ikan dengan hasil yang sangat banyak. Di candi lain dipahat pula, orang yang sedang memasang perangkap ikan dari bambu, dalam beberapa prasasti Jawa kuno disebutkan juga istilah tambak, yang dalam konteks tertentu ditafsirkan sebagai tempat pemeliharaan ikan. Dari beberapa data di atas dapat dipastikan tradisi kehidupan nelayan terus berlangsung dan tetap memegang peran penting dalam kehidupan masyarakat pada masa itu (Paeni, 2009: 131-132).

Kegiatan berburu atau biasa disebut dengan mencari lauk adalah suatu kegiatan yang lazim dilakukan oleh para lelaki. Biasanya binatang tujuan mereka utamanya adalah babi hutan dan rusa, selain binatang-binatang lain yang ada dihutan, seperti ternuk (tapir), kijang, kancil, kura-kura, dan labi-labi. Ada beberapa binatang yang pantang mereka bunuh dan makan, seperti monyet, burung gading. Sebagian besar didasarkan atas anggapan bahwa binatang tersebut seperti harimau adalah hewan peliharaan dewa atau bahkan merupakan perwujudan dewa. Kegiatan berburu biasanya mereka lakukan pada malam hari, dengan alat penerang senter mereka mencari binatang buruannya. Mereka juga menangkap buruannya tanpa senjata yaitu dengan menggunakan jebakan terbuat dari rantingranting pohon dan tali akar atau tali rotan yang kuat, biasanya jebakan dibuat berdasarkan hewan apa yang akan ditangkap. Kegiatan berburu lainnya adalah mencari ikan dengan cara memancing, menangkap ikan dengan tangan, meracun ikan dengan akar tumbuhan. Kegiatan menangkap ikan ini adalah kegiatan yang dilakukan bersama-sama keluarga, biasanya dilakukan oleh para wanita, anakanak pada saat pasca banjir (Paeni, 2009: 107-108).

Para pemburu hanya memakai dhoti pendek. Rambut mereka diikat dengan pengikat kepala, atau dipakai celana 
pendek dengan ikat pinggang dan kaki mereka chappal. Pemburu-pemburu yang lebih berada mengenakan sejenis mantel sebatas pinggang, celana panjang dan sepatu lars (Noerhadi, 2012: 62).

Berburu adalah suatu bentuk mata pencaharian yang mengandalkan teknologi menghadapi binatang buruan yang selalu bergerak sehingga diperlukan suatu teknologi yang memiliki kemampuan untuk mengikuti pergerakan binatang buruan. Biasanya pada model pola kehidupan demikian, peralatan yang digunakan oleh masyarakat tipe ini mengandalkan lontaran yang dapat memperpendek jangkauan antara pemburu dan binatang yang diburu (Paeni, 2009: 56).

\section{Perhiasan Prajurit Atau Tentara}

Tentara memakai kain terdiri dari kain dhoti dengan lipatan-lipatan yang dijahit di belakang sehingga tidak mengganggu gerak-geriknya. Mereka juga memakai jas tangan panjang dan turban di kepala mereka. Sebagai pengganti mantel dipakai sejenis blus pendek, hanya memakai ikat pinggang dan ikat kepala (Noerhadi, 2012: 62).

Pakaian perang terdiri dari celana yang terkancing dari pinggang sampai mata kaki, celana pendek sampai bawah lutut yang terbuat dari kain halus atau sutra, amben atau sabuk yang diikatkan mengelilingi tubuh sebanyak 7-8 kali untuk melindungi tubuh dari lengan sampai pinggang, yang terbuat dari sutra atau kain yang sangat bagus, dilengkapi dengan rompi ketat tanpa kancing yang disebut dengan sangsang, diatasnya ada rompi dengan kancing yang dimulai dari leher sampai perut atau kotan berkancing, dan ditutupi dengan sikapan atau jaket panjang menutupi seluruh tubuh. Tali pedang diikat dipinggang, dan pedang ditaruh disisi kiri sabuk (Raffles, 2015: 58).

\section{Perhiasan Pemusik Atau Seniman}

Menurut Soedarsono dalam

Noerhadi (2012: 6) pada relief candi Borobudur kita temukan adegan yang menggambarkan seorang raja dengan istrinya sedang menikmati tari dan musik. Relief-relief ini menggambarkan tentang pakaian dan perhiasan seorang penari. Tarian ditarikan oleh seorang wanita yang pakaiannya terdiri dari tutup kepala, kalung, kelat-bahu, kain dan sampur (Noerhadi, 2012: 6).

Kesenian sebagai ekspresi hasrat manusia akan keindahan untuk dinikmati, maka ada dua lapangan besar yaitu seni rupa, atau kesenian yang dinikmati langsung oleh mata manusia, seni suara atau kesenian yang dinikmati oleh manusia dengan telinga, dalam seni rupa juga terdapat seni patung, seni relief (termasuk seni ukir), seni lukis dan gamba, dan seni rias. Seni musik ada yang vokal (menyanyi) dan ada juga yang instrumental (dengan alat bunyi-bunyian), dan sastra yang lebih khusus terdiri dari prosa dan puisi (Koentjaraningrat, 2009: 299).

\section{Perhiasana Petani}

Pulau Jawa bagus untuk pertanian karena tanahnya sangat subur, para petani tidak menanam hanya sebatas untuk memenuhi kebutuhan dasarnya, tetapi juga untuk memenuhi kebutuhan lainnya, seperti membeli barang-barang kebutuhan yang sedikit mewah. Bangsa Jawa adalah bangsa petani, dan akhirnya membentuk struktur masyarakat yang khas. Petani mendapat uang dari tanamannya, prajurit dari upahnya, pegawai dari gajinya, para ulama dari sumbangan (zakat) dan pemerintah dari hasil pajak. Kekayaan suatu desa atau provinsi tergantung dari luas dan suburnya tanahnya, sistem pengairannya, serta jumlah kerbau yang dimiliki. Karena kondisi tanahnya yang sangat subur dan hanya membutuhkan sedikit usaha untuk menghasilkan hasil panen yang melimpah, maka petani di Jawa tidak berusaha lebih keras untuk meningkatkan tarap kehidupannya. Beras adalah makanan pokok bagi semua kalangan masyarakat di Jawa, dan merupakan tanaman yang paling banyak 
dipelihara. Setiap harinya petani bisa mendapatkan 4-5 kantung kati, satu kantung kati sama dengan satu seperempat liter, jumlah yang cukup untuk makan orang dewasa, tenaga wanita di Jawa terhitung sama kuat dengan tenaga laki-laki, sehingga satu keluarga dapat memiliki 8-10 tenaga kerja (Raffles, 2015: 70-71).

Pada zaman dahulu kain yang digunakan untuk melakukan pekerjaan harian, seperti mengerjakan kebun, selalu bercirikan warna putih bercampur hitam. Kain-kain ini tidak memiliki motif, warna yang menonjol bervariasi antara hitam dan putih. Namun, pada kebanyakan orang lebih dominan warna puti.dilihat dari alasan penggunaan warna, menurut mereka, kain dengan warna putih diselang-selingi warna hitam lebih cepat proses penenunannya dibandingkan dengan kain yang berwarna lainnya. Selain alasan ini, juga dikatakan bahwa kain untuk melakukan kerja bbiasanya cepat kotor dan mudah rusak sehingga selalu harus diganti untuk musimmusim kerja ladang berikutnya. Berkaitan dengan hal ini, dikatakan juga bahwa pekerjaan menenun yang biasanya dilakukan oleh kaum wanita pada masa sesudah panen, selalu mengalami hambatan waktu. Pada masa-masa seperti itu kaum wanita selalu disibuki dengan tugas menenun kain-kain adatbaik untuk lelaki maupun untuk wanita yang akan digunakan segala keperluan adat, terkadang mereka juga disibuki dengan menenun kain yang digunakan dirumah. Oleh sebab itu pilihan warna putih lebih menghemat waktu dalam proses pembuatannya (Depdikbud, 1991: 12).

\section{Jenis-Jenis Perhiasan Mataram Kuno} Jenis-jenis perhiasan Mataram kuno; (1) Perhiasan pada kepala sejak dulu dipakai untuk mengubah bentuk kepala dan menambah tinggi atau keanggunan bagi pemakainya; (2) Perhiasan pada bawah leher, sampai bagian dada. Perhiasan daerah ini sekaligus membawa ciri-ciri seksual sekunder, misalnya lebarnya pundak pada pria atau montoknya bahu dan payudara wanita. Pakaian atau perhiasan pada bagian ini memang dimaksudkan kerapkali untuk meningkatkan daya tarik seksual pemakainya; (3) Perhiasan pada pinggang, yang terpenting dari perhiasan bagian pinggang adalah menonjolkan bentuk pinggang yang ramping dengan tiga lipatan pada bagian atas perut, bulat dan kedalam pusar maupun dianggap suatu yang membanggakan; (4) Perhiasan pada pusar sampai di atas lutut, bagi wanita ini adalah bagian yang dianggap menarik, terutama dihubungkan dengan ciri keibuan, tetapi dilain pihak bagian perut bagi pria dengan kecenderunngan membuncit di hari tua dianggap menjengkelkan dan kurang menguntungkan;(5) Perhiasan pada bawah lutut, bagian bawah lutut ini kerapkali dianggap kurang menyenangkan untuk di tampilkan sehingga sebaiknya ditutupi (Noerhadi, 2012: 12).

Dalam rangka memperindah penampilan sehari-hari, diperlengkapi lagi dengan perhiasan-perhiasan. Perhiasan tersebut ada yang dibuat dari emas, dan perak. Banyak diantara perhiasan yang dibuat dari perak sering disepuh dengan emas. Diantara perhiasan yang dipakai antara lain perhiasan-perhiasan yang digunakan ditelinga untuk orang tua subang dan untuk anak gadis anting-anting, dileher dipakai pula perhiasan yang disebut kalung, ditangan dipakai gelang tangan, penggunaan perhiasan yang paling meriah dipakai pada saat menggunakan pakaian adat resmi ataupun pada saat memakai pakaian pengantin. Pada saat itu mereka memakai sebanyak mungkin perhiasan yang dimilikinya (Depdikbud, 1993:24-25).

\section{Perhiasan Mataram Kuno}

1) Mahkota dapat berupa perhiasan atau berupa susunan rambut yang tinggi dan diberi hiasan-hiasan 
seperti permata (Noerhadi, 2012: 13).

2) 2) Jamang adalah tepian mahkota pada perbatasan dahi dan rambut (Noerhadi, 2012: 13). Jamang adalah tepian mahkota pada perbatasan dahi dan rambut. Piring emas atau jamang yang dipakai di dahi, seperti halnya perhiasan yang dipakai di leher dan lengan, sekarang tidak lagi digunakan, kecuali saat upacara pernikahan atau upacara-upacara lain yang membutuhkan pemakaian baju adat dengan semua kelengkapannya (Raffles, 2015: 58).

3) Subang atau yang biasa disebut anting-anting adalah perhiasan yang dikenakan pada daun telinga yang berlubang panjang (Noerhadi, 2012: 13). Perhiasan subang atau antinganting dikenakan pada telinga seseorang pada dasarnya tidak menunjukkan perbedaan bagi kelompok-kelompok sosial pada masyarakat. Hal ini disebabkan karena perhiassan tersebut dipakai oleh seluruh lapisan masyarakat (depdikbud, 1987: 45).

4) Kalung terdiri dari dua golongan yaitu kalung yang terdiri dari satu susun, kalung yang terdiri dari dua susun dan terkadang dipakai keduanya (Noerhadi, 2012: 13). Kalung pada masa sekarang tidak lagi menggunakan manik-manik sebagai perhiasan di leher, biasanya digunakan emas murni ataupun dari imitasi. Segala perlengkapan manikmanik sekarang telah beralih fungsi ke perhiasan yang dipakai dalam tarian adat atau dalam upacara adat. yang masih terdapat pada zaman sekarang ialah fungsi sosial yang ditentukan oleh bahan perhiasannya. Jika bahan yang digunakan emas murni menunjukan status sosial pemakainya tinggi sedangkan jika bukan emas menentukan status sosial pemakainya rendah atau rakyat biasa (depdikbud, 1987: 68)

5) Upavita atau selempang kasta berupa semacam tali polos atau untaian mutiara. Dipakai dari bahu turun ke pinggang kanan (Noerhadi, 2012:13).

6) Kelat-bahu adalah perhiasan yang dipakai pada kedua lengan atas, ada yang berhiaskan permata dan tanpa hiasan permata (polos) (Noerhadi, 2012: 13).

7) Gelang tangan dipakai pada pergelangan tangan kanan dan kiri. Dapat berupa untaian mutiara, tanpa perhiasan mutiara atau polos (Noerhadi, 2012: 13). Makna gelang yang masih terbawa sampai sekarang adalah makna yang menentukan status sosial. Jika seorang wanita memakai gelang yang terbuat dari emas dalam jumlah yang banyak maka status sosialnya tergolong tinggi sebaliknya jika masih menggunakan perak maka status sosialnya tergolong biasa atau rakyat biasa (depdikbud, 1987: 70).

8) Selendang adalah perhiasan yang dipakai mulai dari bahu kiri dan jatuh di pinggang kanan atau digantungkan di pundak/leher dan kedua ujungnnya berjuntai di bagian belakang badan. Terkadang dipakai juga untuk ikat kepala (Noerhadi, 2012: 13).

9) Uncal adalah perhiasan yang digantungkan pada ikat pinggang atau ikat pinggul, terjuntai didepan paha, dapat berupa hiasan atau tali yang terjulur di kiri dan kanan (Noerhadi, 2012: 13).

10) Ikat pinggang dipakai disekeliling pinggang dan kedua ujungnya diikat, dipakai agar kain tidak merosot. Ikat pinggang bisa dipakai satu atau dua susun, bahkan tiga susun (Noerhadi, 2012: 13). 
11) Ikat pinggul adalah perhiasan yang dipakai pada bagian tubuh di sekitar pinggul (Noerhadi, 2012: 13).

12) 12) Perhiasan kain pada Wanita, terdiri dari kain pendek sampai lutut dan kain panjang sampai pergelangan kaki (mata kaki). Kain ini diputar sekeliling badan dan dipakai mulai dari bawah pusar atau dari pinggang ke bawah. Sedangkan pada pria, kain terdiri dari kain pendek di atas lutut, kain pendek sampai lutut dan kain panjang sampai tengah betis bahkan panjang sampai pergelangan kaki atau mata kaki. Atau kain yang diangkat pendek sehingga tampak seperti cawat. Kain ini dipakai disekeliling badan mulai dari bawah pusar (Noerhadi, 2012:

13) 13). Kain yang digunakan dirumah proses menenunnya lebih lama dibandingkan dengan proses penenunan kain yang digunakan untuk diluar rumah, latar belakang penggunaan kain pada kain ini adalah untuk menunjukkan kerajinan kerja dan kemampuan ekonomi seseorang.13) Gelang kaki dipakai pada pergelangan dua kaki, dapat berupa untaian mutiara atau polos tanpa hiasan (Noerhadi, 2012:

14) 13). Masyarakat pada masa lampau baik laki-laki maupun perempuan memiliki perhiasan pada betis yang terbuat dari logam campuran perak dan tembaga. Makin banyak gelang yang dipakai makin tinggi status sosial seseorang di dalam masyarakat (depdikbud, 1987: 71).

15) 14) Ikat dada adalah perhiasan yang dipakai atau dilingkarkan pada batas antara dada dan perut diikat menempel pada bahan (Noerhadi, 2012:13).

16) 16) perhiasan Ikat lutut pada pria adalah perhiasan yang dipakai agar posisi duduk lebih enak, dengan cara menekuk lutut kemudian diikat dengan tali ke pinggang. Sedangkan wanita tidak memakai perhiasan ikat lutut (Noerhadi, 2012: 13).

Selain perhiasan-perhiasan di atas, masih ada perhiasan lain yang mempunyai peranan penitng yaitu bunga. Bunga merupakan pelengkap dalam bersolek, dipakai oleh wanita dan pria untuk menghias rambutnya dan ditaruh dibelahan rambut, untuk menjadi penghias telinga, bunga pun menjadi alat persembahan (Noerhadi, 2012: 15).

\section{SIMPULAN}

Seni perhiasan dalam kebudayaan Mataram kuno terbagi berdasarkan 8 golongan sebagai berikut: golongan pertama adalah kaum bangsawan yang mempunyai perhiasan dengan taraf lengkap seperti mahkota, jamang, upavita, kelat bahu, gelang tangan dan gelang kaki, semua perhiasan yang dikenakan oleh kaum bangsawan tentunya sesuai dengan kedudukannya di dalam masyarakat. Golongan kedua adalah golongan agamawan yang memiliki perhiasan wajib yaitu upavita atau selempang kasta, golongan agamawan terbagi menjadi dua yaitu golongan agamawan istana yang memiliki perhiasan yang lebih lengkap dibandingkan golongan agamawan yang berada di luar istana. Golongan ketiga adalah golongan pedagang yang memiliki perhiasan berupa mahkota kecil, kelat bahu, anting-anting, gelang tangan dan gelang kaki, sedangkan pedagang yang berada di luar memiliki perhiasan yang sederhana. Golongan keempat adalah golongan rakyat biasa yang memiliki perhiasan sederhana, mereka menenun sendiri kain yang mereka pakai karena faktor ekonomi mereka hanya mencukupi kebutuhan pokok. Golongan kelima adalah golongan nelayan dan pemburu, nelayan saat sedang melaut tidak mengenakan perhiasan dan pemburu yang sedang berburu di hutan hanya sedikit memakai perhiasan. Golongan keenam adalah 
golongan prajurit dan tentara yang memiliki perhiasan disesuaikan dengan aktifitas mereka, kain yang dipakai tentara adalah kain yang memiliki lipatan dibelakang untuk memudahkan gerakan mereka. Golongan ketujuh adalah golongan pemusik atau seniman memiliki perhiasan seperti selendang, kalung, kelat bahu, gelang tangan dan gelang, perhiasan yang mereka pakai disesuaikan dengan kegiatan mereka yang mengharuskan memiliki penampilan menawan. Golongan kedelapan adalah golongan petani mereka tidak memiliki banyak perhiasan, karena aktifitas mereka bekerja di ladang dan sawah.

\section{DAFTAR PUSTAKA}

Akbar, Setiady Purnomo dan Usman Husaini. 2014. Metodologi Penelitian Sosial. Jakarta: Bumi Aksara.

Arikunto, Suharsimi. 2013. Prosedur Penelitian Suatu Pendekatan Praktik. Jakarta : Rineka Cipta.

Darini Ririn. 2013. Sejarah Kebudayaan Indonesia Masa Hindu-Budha. Yogyakarta: Ombak.

Depdikbud. 1987. Arti Lambang Dan Fungsi Tata Rias Tradisional Pengantin Daerah Nusa Tenggara Timur. Jakarta: Depdikbud.
1991. Pakaian Adat Tradisional Daerah Provinsi Nusa Tenggara Timur. Yogyakarta: Depdikbud 1977. Goegrafi Daerah Jawa Tengah. Jakarta: Depdikbud Koentjaraningrat. 2009. Pengantar IImu antropologi. Jakarta: Rineka Cipta.

Munandar Agus Aris. Borobudur. Jurnal Konservasi Cagar Budaya.Vol III No. 3, Desember 2009.

Noerhadi Inda Citranda. 2012. Busana Jawa Kuno. Depok: Komunitas Bambu.

Paeni Mukhlis. 2009. Sejarah Kebudayaan Indonesia Sistem Teknologi. Jakarta: Rajawali Pers.

Prasetyo, Bambang. 1993. Borobudur, Pawon dan Mendut. Yogyakarta: Kanisius.

Raffles Thomas Stamford. 2015. The History of Java. Yogyakarta: Penerbit Narasi.

Soekmono. 1991. Satu Abad Usaha Penyelamatan Candi Borobudur. Yogyakarta: Kanisius

Soetarno. 2003. Aneka Candi Kuno di Indonesia. Semarang : Dahara Prize Semarang

Suwardono. 2013. Sejarah Indonesia Masa Hindu-Budha. Yogyakarta: Ombak.

Suyono. 2003. Peperangan Kerajaan di Nusantara Penelusuran Kepustakaan Sejarah. Jakarta: Grasindo.

Wiryomartono Bagoes. 1995. Seni Bangunan dan Seni Binakota Di Indonesia. Jakarta: Gramedia Pustaka Utama. 